burned in air with ordinary burners. Gasengines, moreover, are within the intelligence of butlers, gardeners, and coachmen: they are always ready for work, they attain their maximum efficiency at once, and they can be stopped in a moment.

In England the opportunities of using waterpower are few and far between. The power of the tide or that of a flow of the river is very small when utilized within the limits of ordinary people. The whole flow of the Thames through London bridge would maintain only 800 lamps. In Scotland, however, the case is somewhat different. There several persons have utilized the water stored up in lakes. Many wonder why the wind is never used; but, apart from its uncertainty and unreliability, there is the fact that the power developed by the best windmills is, on the average, but very small.

After referring to the sources of power, $\mathrm{Mr}$. Preeceturned his attention to the dynamo, and claimed that science, since the expiration of the Gramme patent, has converted a crude instrument into the most powerful converter of energy that exists. The forms of dynamo, he said, are being whittled down to two or three recognized shapes; but "as long as the spirit of rivalry is stirred up by competition and emulation, so long shall we have some manufacturer who will make a change for the sake of a change, and who will advertise his wares as the best in the world." Mr. Preece holds that little remains to be desired in the quality or price of dynamos, and that a well-constructed dynamo, kept clean and well lubricated, never overworked, should last a lifetime without much attention except to the brushes and commutator.

It is by means of the secondary battery that regularity and uniformity of current are maintained in isolated installations; and it supplies a reserve of force that renders one free from accident to engine or dynamo. Its early failures disappointed many; but Mr. Preece hopes that it has ' sown its wild oats,' and that it has become a mature, sober, practical instrument. Sir William Thomson writes, " My cells have worked to perfection. It is the greatest possible comfort to us in the house to have the light with satisfactorily equal brilliancy at all hours of the night and day, and every day in the week. I have now cut off the gas at the meter, so that there is absolutely none used in the house. I have no oil-lamps, and have not used so much as a single quarter of a candle within the last three months, and have the electric light in every part of the house where light can possibly be wanted by night or by day." Mr. Preece now uses the secondary batteries, not, as formerly, as regulators to his engine, but for the storage of electricity, charging them during the day, and discharging them through the lamps at night. He maintains that the durability of his cells is most satisfactory, and that he can see no reason why they should not last ten years at least.

Of the lamps, Mr. Preece could not chronicle so great progress as that of dynamos and secondary batteries, and he held that a good standard glowlamp has not yet been devised. He would prefer a 10-candle lamp, working under a pressure of 50 volts, and requiring half an ampère: that would mean the absorption of 25 watts, or two and a half watts per candle. The life of such a lamp would not be very great; but, if it were cheap enough, one would not mind frequent renewals. Makers of lamps seem to consider that there is great credit in securing long life; but this may be unfortunate, considering the deterioration of glow-lamps with age, owing to the wasting-away of the carbon and its deposition on the glass globe. Mr. Preece would have a lamp such that we could afford to give it a 'short and merry life.'

There is felt in England, on account of the small development in the industry, a difficulty in obtaining experienced workmen; and in some cases it has been necessary to send nearly the length of the island for men to put in the wires and machinery.

Mr. Preece's estimation of the cost is just twice that of gas; but this, whether too high or too low, seems to be in doubt, and it is certain that the cost is largely dependent upon the extent to which the light shall be used. Considerable impatience is felt at the restrictions imposed by the act of 1882, and the council of the Society of arts is taking an active part in supporting the measure now before the house of lords, intending to extend the facilities for introducing electric lighting. This act is understood to be under the direct supervision of Lord Rayleigh.

\section{THE PROPOSED FISHERIES BOARD OF GREAT BRITAIN.'}

I AM of opinion that the less the government interferes with any branch of industry, the better, and that, as a general rule, the cost and trouble of obtaining such scientific information as is necessary for the successful prosecution of a branch of industry ought to fall upon those who profit by it, and not upon the general body of the

1 Letter in response to a request from the secretary of the Society of arts for Professor Huxley's views as to the constitution of a fisheries board. 
tax-payers. I do not think that any sane man would propose to establish a government office, composed of chemists and metallurgists, for the purpose of managing the business of the iron-masters.

The case of the fishing industry, however, is peculiar. The different classes of fishermen tend to encroach on one another's liberties; and in the case of sea-fisheries the nation at large is proprietor, and has an interest in their being properly worked. Moreover, beyond the three-mile limit the interests of English fishermen may come into conflict with those of foreigners, and give rise to international questions of great difficuity and delicacy. Hence I have no doubt that some department of the government ought to be in close relation with the fisheries, ought to be able to interfere with them to some extent and under certain circumstances, and ought to be able to institute or undertake such scientific inquiries as may be needful in order to obtain satisfactory data for its action.

My first connection with fishery questions dates back now about a quarter of a century, and from that time to this I have taken every opportunity of urging the formation of a government department, such as I imagine is now about to be established, empowered to deal with the fisheries on these principles.

I think that such a fishery department should -

1. Collect accurate statistical and other information respecting the fisheries of England and bearing upon fishery interests in general, and present a yearly report, to be laid before parliament, based thereupon.

2. That it should be empowered to inquire into grievances of fishermen and suggestions for improvement of the fisheries. Hitherto the only method open to those who were, or supposed themselves to be, aggrieved was to get a royal commission of inquiry appointed. Within my experience, three of these commissions have inquired at intervals af eight or nine years, at great cost of trouble and money, into the same questions regarding the sea-fisheries, and have arrived at practically the same results.

3. That it should have power of inquiry to make orders regulating or restricting acts of fishery.

4. That it should be empowered to obtain such scientific assistance as may be needful.

It is to this last point that the questions addressed to me are more particularly directed; but I could hardly have answered them satisfactorily unless I had sketched forth my general views as to the justification and the limits of state interference in fishery matters. I have had something to do both with science and with administration, and it is in the interest of both that I express my strong conviction that they ought to be kept separate.

The function of the man of science is to ascertain facts, and give advice based upon that which he has ascertained. He may be the most competent person in the world to do that, and, at the same time, wholly unfit for administrative duties. If, again, we consider the four kinds of action to which, I believe, the operations of a fishery department should be restricted, what is the advantage of setting a skilled naturalist to collect and digest statistics, or to draw up regulations and orders, or to weary out his soul in the routine business of an administrative office? What he is wanted for is to act, first, as an assessor in inquiries, and, secondly, as an investigator of such problems as bear directly upon those fishery questions in which the general public is interested. For example, the nation at large has an interest in providing against the practice of unduly wasteful modes of fishing, as tending to the wanton destruction of its property ; and I should say that any amount of money bestowed upon the scientific investigation of the effect of some modes of fishing might be well spent.

I am strongly of opinion that the best method of bringing science into its proper relation with the fishery department is that the latter, when it requires a scientific answer for an inquiry, or when it desires that a scientific problem should be thoroughly investigated, should apply to the president and council of the Royal society to nominate a person or persons to undertake the work. That is a course frequently pursued by other governmental departments, and it works very satisfactorily. However, if it should be thought better to have a permanent adviser, or a permanent committee of reference, I see no great objection to the adoption of either of these plans.

But what I desire to repudiate as strongly as possible, in the name and the interest of science, no less than in that of the working fisherman, is the proposal which I see continually pressed in letters addressed to the papers, to appoint a body of scientific men to ' manage' the fisheries. In the first place, the proposition is futile, for anybody who knows any thing about the feeling among the smack owners and working fishermen is aware that they would not listen to such a proposal for a moment. In the second place, the notion that the fisheries want managing by a government office, and that the fishing business, like every other, ought not, as far as possible, to be left to manage itself, is, in my opinion, utterly foolish and mischievous. And, in the third place, if the fisheries were to be thus managed, men of science are no more the right people to be intrusted with 
managing fishery affairs than a landsman who happens to be master of the theory of navigation is the right man to be trusted with steering an ironclad.

The whole lesson of my somewhat lengthy and varied experience of fishery matters may be summed up thus :-

1. Don't meddle, unless you have good grounds for believing that you know what the effect of your meddling will be.

2. Listen to all that the scientific men without practical knowledge and the practical men without scientific knowledge have to say, but give to neither the power of directly interfering with such a large and important branch of industry as fishing.

3. Collect all the information that is to be had, so that the country may know year by year how the fisheries really stand; make that information accessible to the people who are engaged in the fishing industry; inquire into real or supposed grievances; and regulate or restrict, experimentally, on good cause shown.

4. Let the department charged with these duties obtain such scientific help as is needful from persons of recognized scientific competency, who are not under the control of the administrative department, and are not responsible to any one for the conclusions at which they may arrive. Moreover, let all scientific inquiries thus undertaken be strictly relevant, not merely to fishery matters, but to questions with which the state may properly deal as the representative of the general interest.

If the government is to be asked to give a body of scientific men a roving commission to inquire into the natural history of the seas and rivers of England, let that issue be put plainly before the minister to whom the application is made. But I do not see what the board of trade has to do with such ' aid to science,' nor why it is desirable that the gentlemen who are to be intrusted with this very considerable enterprise should have the ' management of the fisheries' - which means the power of meddling with a great industrial interest - thrown in as a sort of hors d'oeuvre.

March 20

T. H. HuXLEY.

\section{EXPLOSIONS IN COAL-MINES.}

ATtention has been called to the connection which exists between gas-explosions in coal-mines and certain atmospheric conditions, which is expressed by saying that the number of such explosions is very considerably greater under low atmospheric pressure (under so-called barometric depression) than with a normal or high barometer.
This is not a newly discovered fact, for it was recognized by Dickinson as early as 1852 ; and for nearly ten years past barometers have been used in many English coal-mines for observing the condition and changes of atmospheric pressure, and estimating therefrom, to some extent, the danger which may come from the latter source. But there is a growing conviction that the whole question needs further investigation, and particularly that experimental tests are necessary. Such tests, however, are very expensive, and for that reason little has been done hitherto in that direction. All the more noteworthy, therefore, are the numerous experiments which were undertaken last summer at the mines of Archduke Albert in Karwin, and which were on such a scale that the working of the entire mine was suspended at times in order to give a free field to the scientific investigations. Professor Suess has recently given an account of these important investigations in the geological institute at Vienna.

The district in which these observations were made comprises the greatest part of the archducal Gabriela mine. This portion obtains its fresh air from the Gabriela shaft, while the principal airshaft, 500 metres to the west, serves as the up-cast shaft. At the latter a Quibal ventilator of 7.04 metres diameter was in operation during the whole course of the experiments. A similar ventilator of 12 metres diameter has been introduced recently.

The seams of the Gabriela mine belong to the most easterly portion of the Ostran-Karwin district, just on the edge of the Carpathian Mountains; and the mine joins the district of the Johann-Schacht where the accident of March 6 , 1883, occurred. The stratification is nearly horizontal. On one occasion, after work in the mine had been stopped for six hours, the freshly exposed surface, where the miners had been at work, gave a crackling, blowing, and slightly hissing sound over its whole extent; and the escape of gas was detected not only by the lamp, but by the ear. Many of the puddles of water on the floor of the level were in slight agitation from the gas bubbling up through them. The old surfaces, however, were quiet, and experience has shown that the portions of the seam lying nearest workings lose their gas sooner or later, and cease to be dangerous. For the reason above explained, also, the working of drifts running directly into the seam requires the greatest precaution, and in the whole Ostran-Karwin district double workings are carried on in the deep levels for the sake of ventilation. The escaping gas is carried along by the draught produced by the ventilation, but local accumulations are unavoidable. 